\title{
Tat-HSP22 inhibits oxidative stress-induced hippocampal neuronal cell death by regulation of the mitochondrial pathway
} (1) crossanat $^{2}$

\author{
Hyo Sang Jo ${ }^{1 \dagger}$, Dae Won Kim² ${ }^{2 \dagger}$, Min Jea Shin ${ }^{1 \dagger}$, Su Bin Cho', Jung Hwan Park, Chi Hern Lee ${ }^{1}$, Eun Ji Yeo ${ }^{1}$,

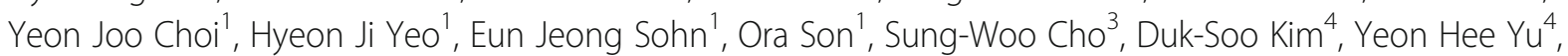 \\ Keun Wook Lee', Jinseu Park', Won Sik Eum ${ }^{1 *}$ and Soo Young Choi ${ }^{1 *}$
}

\begin{abstract}
Oxidative stress plays an important role in the progression of various neuronal diseases including ischemia. Heat shock protein 22 (HSP22) is known to protect cells against oxidative stress. However, the protective effects and mechanisms of HSP22 in hippocampal neuronal cells under oxidative stress remain unknown. In this study, we determined whether HSP22 protects against hydrogen peroxide $\left(\mathrm{H}_{2} \mathrm{O}_{2}\right)$-induced oxidative stress in HT-22 using Tat-HSP22 fusion protein. We found that Tat-HSP22 transduced into HT-22 cells and that $\mathrm{H}_{2} \mathrm{O}_{2}$-induced cell death, oxidative stress, and DNA damage were significantly reduced by Tat-HSP22. In addition, Tat-HSP22 markedly inhibited $\mathrm{H}_{2} \mathrm{O}_{2}$-induced mitochondrial membrane potential, cytochrome $\mathrm{c}$ release, cleaved caspase-3, and Bax expression levels, while Bcl-2 expression levels were increased in HT-22 cells. Further, we showed that Tat-HSP22 transduced into animal brain and inhibited cleaved-caspase-3 expression levels as well as significantly inhibited hippocampal neuronal cell death in the CA1 region of animals in the ischemic animal model. In the present study, we demonstrated that transduced Tat-HSP22 attenuates oxidative stress-induced hippocampal neuronal cell death through the mitochondrial signaling pathway and plays a crucial role in inhibiting neuronal cell death, suggesting that Tat-HSP22 protein may be used to prevent oxidative stress-related brain diseases including ischemia.
\end{abstract}

Keywords: Tat-HSP22, Oxidative stress, Apoptosis, Ischemia, Protein therapy

\section{Introduction}

Heat shock proteins (HSPs) are known to be stressinducible proteins and are found in all organism. They play an important role in cell survival in cells exposed to biological stresses such as oxidative stress or chemical stress [1-3]. The HSP family are classified based on their molecular weight including HSP70, HSP90, HSP110. Small HSPs are highly conserved and well characterized as playing the role of molecular chaperones, and having a protective function against biological stress [4-7]. Among HSPs, HSP22 is known as a member of the family of small HSPs containing $\alpha$-crystal domains, preferentially expressed in heart, and having protective

\footnotetext{
* Correspondence: wseum@hallym.ac.kr; sychoi@hallym.ac.kr

${ }^{\dagger}$ Equal contributors

'Department of Biomedical Science and Research Institute of Bioscience and Biotechnology, Hallym University, Chuncheon 24252, Korea

Full list of author information is available at the end of the article
}

effects against various conditions such as oxidative stress, aging, cancer, and apoptosis [8-11]. Other studies have demonstrated overexpression of HSP22 promotes cardioprotection in an ischemic preconditioning animal model by inhibition of iNOS production and mitochondrial dysfunction [12, 13].

The mitochondria play an important role in multiple cellular processes including apoptosis [14]. Mitochondria are known as one of the major sources of reactive oxygen species (ROS) production as a by-product of cellular processes. Excessive ROS causes damage to macromolecules, subsequently leading to mitochondria dysfunction and cell death [14-16]. Other studies have showed that mitochondrial dysfunction is associated with ROS production and mitochondria as well as with ischemic damage [12-16]. However, the exact biological function and precise mechanism of HSP22 protein in ischemic neuronal damage remains poorly understood. 
Protein transduction domains (PTDs) facilitate the delivery of molecules including proteins into cells or tissues. Thus, PTDs were widely used as a tool to investigate the effect of target proteins in a number of diseases [17-20]. Many studies have demonstrated that PTD fusion protein transduced in vitro and in vivo and markedly inhibited stress induced cell death [21-26].

In this study, we cloned, expressed, and purified the Tat-HSP22 protein to examine the effect of Tat-HSP22 in ischemic neuronal damage. Our data demonstrate that Tat-HSP22 protein significantly inhibits oxidative stress-induced hippocampal HT-22 cell death and mitochondrial dysfunction, suggesting Tat-HSP22 protein may allow for the development of a therapeutic protein for neuronal diseases including ischemia.

\section{Results}

\section{Identification of cell permeable Tat-HSP22 protein}

The full length human HSP22 gene was obtained from a liver cDNA library using PCR. The produced gene was digested with restriction enzymes (Xho I and $\mathrm{Bam} \mathrm{HI}$ ) and the gene was cloned into a Tat expression vector to produce cell permeable Tat-HSP22 protein. As shown in Fig. 1a, the resulting Tat-HSP22 protein expression vector contained histidine residue and Tat peptide whereas a HSP22 expression vector was constructed as a control without the Tat peptide. The constructed Tat-HSP22 and control HSP22 protein expression vectors were confirmed by digestion with the same restriction enzymes (Xho I and Bam HI) and DNA sequencing analysis (data not shown).

To purify the Tat-HSP22 and control HSP22 protein, the proteins were induced by adding $0.5 \mathrm{mM}$ IPTG and cultured at $37{ }^{\circ} \mathrm{C}$ for $4 \mathrm{~h}$. After expression of Tat-HSP22 and control HSP22 proteins, these proteins were purified using Ni-NTA affinity chromatography. Subsequently, we performed PD-10 column chromatography to removed salt from the purified proteins. SDS-PAGE and Western blot analysis using an anti-histidine antibody showed that purified Tat-HSP22 and control HSP22 protein bands correspond with the expected molecular weight of HSP22 protein (Fig. 1b and c).

Transduction ability of Tat-HSP22 protein into HT-22 cells To determine whether Tat-HSP22 proteins transduced into hippocampal HT-22 neuronal cells, HT-22 was treated with Tat-HSP22 or control HSP22 proteins (0.5-5 $\mu \mathrm{M})$ for $2 \mathrm{~h}$ or with Tat-HSP22 or control HSP22 proteins $(5 \mu \mathrm{M})$ over various time periods (10-120 min). The levels of transduced Tat-HSP22 protein were measured by Western blotting using an antihistidine antibody. Westering blot analysis indicated that

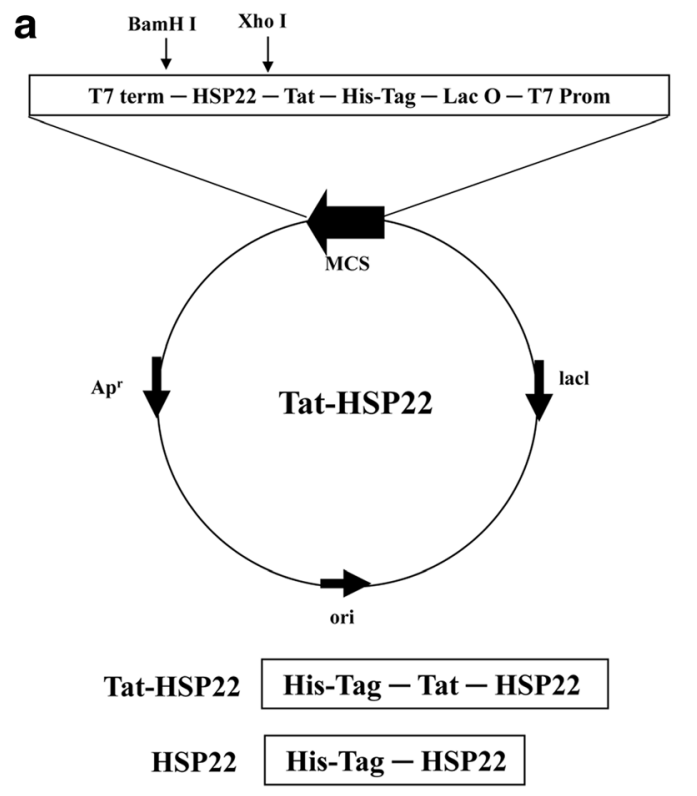

b

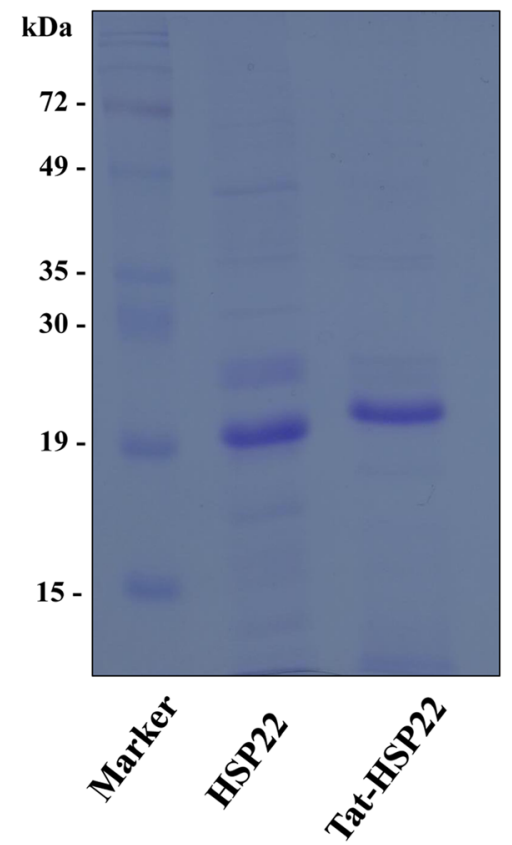

C

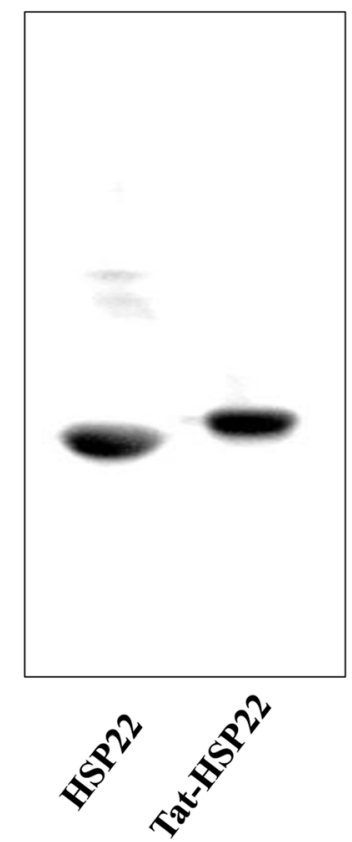

Fig. 1 Construction and purification of Tat-HSP22 protein. a Diagram of expressed Tat-HSP22 and control HSP22 proteins. Tat-HSP22 expression vector was constructed using pET15b vector. Purification of Tat-HSP22 and control HSP22 protein. After proteins were expressed by IPTG, the proteins were purified using Ni-NTA affinity chromatography. Then, purified proteins were analyzed by b $12 \%$ SDS-PAGE and c Western blot analysis with an anti-histidine antibody 
Tat-HSP22 protein transduced into HT-22 cells concentration- and time-dependently, whereas the control HSP22 protein was not detected in the cells (Fig. 2a and b).

To evaluate how long transduced Tat-HSP22 protein is stable in HT-22, HT-22 was exposed to Tat-HSP22 protein for $2 \mathrm{~h}$ and the cells were cultured for various times to assess the stability of Tat-HSP22 protein. TatHSP22 protein stability was determined by Western blot analysis using an anti-histidine antibody. Significant levels of transduced Tat-HSP22 proteins persisted for $36 \mathrm{~h}$ in HT-22 cells (Fig. 2c). We also examined transduced Tat-HSP22 distribution using fluorescence microscopy analysis. As shown in Fig. 3a, the green fluorescence signals were not evident in the control HSP22 protein treated cells. However, more green fluorescence signals were evident in the cytosol and nucleus of cells treated with Tat-HSP22 protein than was evident in the control HSP22 protein treated cells, indicating that Tat-HSP22 protein transduce into HT-22.

\section{Tat-HSP22 protein inhibits against $\mathrm{H}_{2} \mathrm{O}_{2}$-induced $\mathrm{HT}-22$} cell death

To investigate the effects of Tat-HSP22 protein against HT-22 cell death, a WST-1 assay was performed. HT-22 cells were treated with different doses of Tat-HSP22 protein $(1-5 \mu \mathrm{M})$ for $2 \mathrm{~h}$ in the presence or absence of $\mathrm{H}_{2} \mathrm{O}_{2}(1 \mathrm{mM})$ for $12 \mathrm{~h}$. The cell viability of HT-22 cells is shown in Fig. 3b. Our results showed that transduced
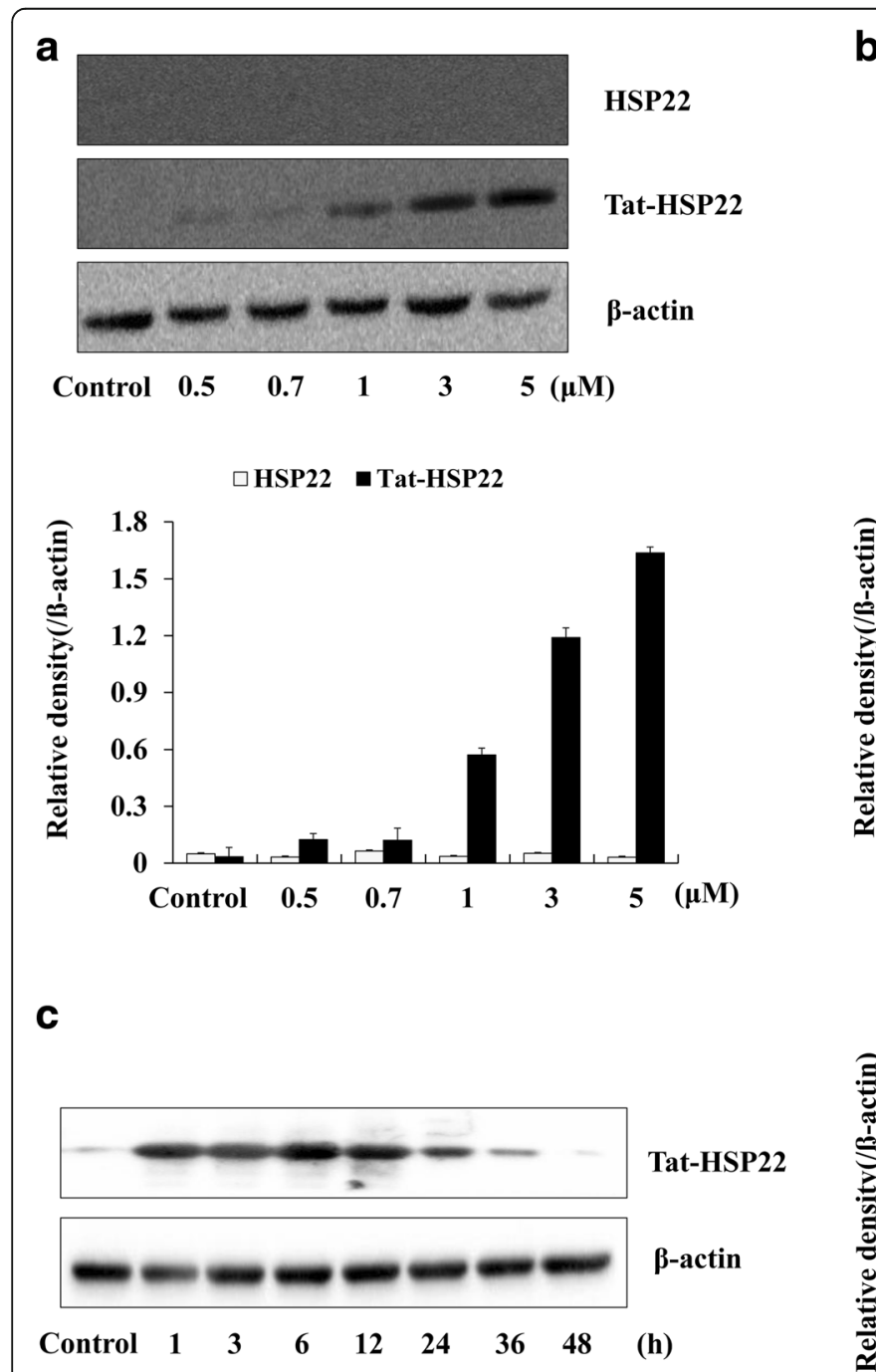

b

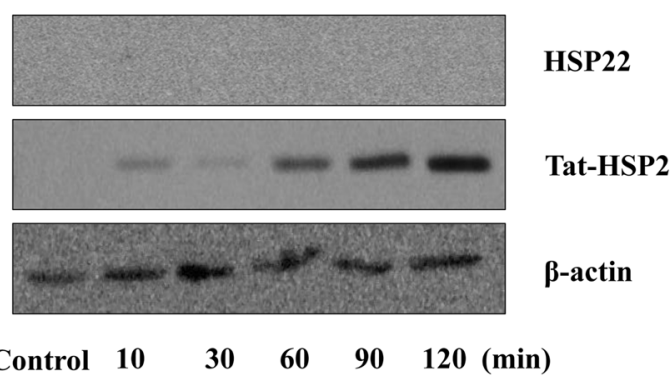

$\square$ HSP22 $\square$ Tat-HSP22
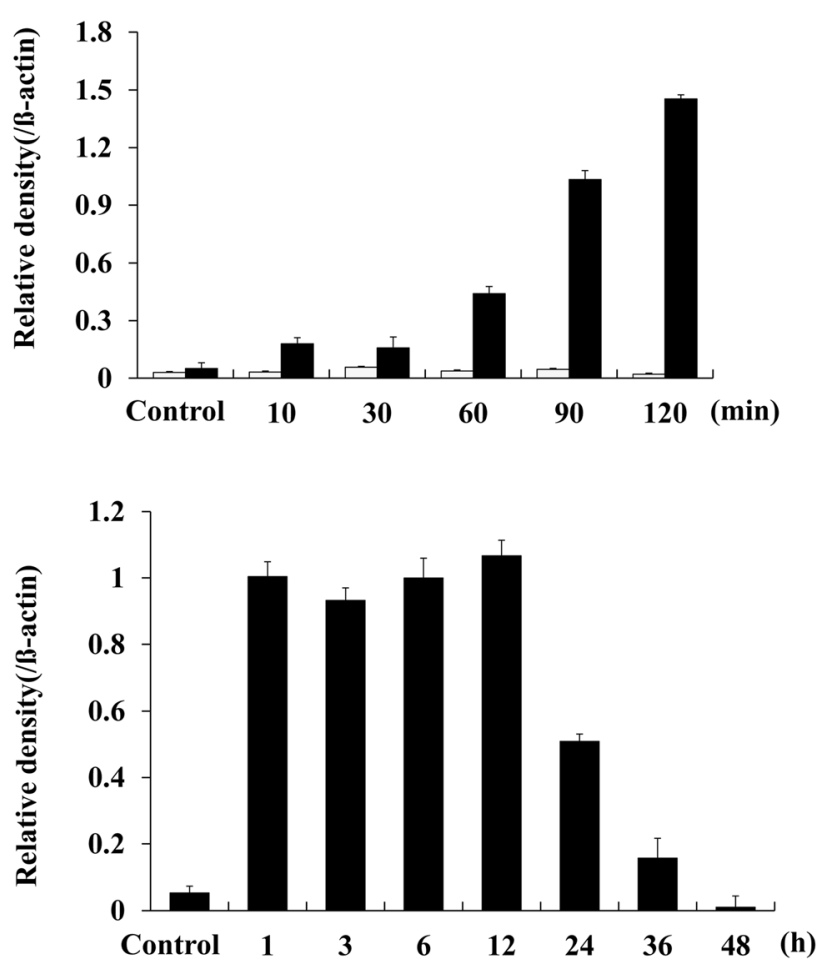

Fig. $\mathbf{2}$ Transduction efficiency of Tat-HSP22 protein into HT-22 cells. a Tat-HSP22 and control HSP22 proteins (0.5-5 $\mu$ M) were added to the culture media for $2 \mathrm{~h}$, $\mathbf{b}$ Tat-HSP22 and control HSP22 proteins $(5 \mu \mathrm{M})$ were added to the culture media for 10-120 min and analyzed by Western blot and the band intensities were measured by densitometer. $\mathbf{c}$ Intracellular stability of Tat-HSP22 protein. The cells pretreated with $5 \mu \mathrm{M}$ Tat-HSP22 protein were incubated for 1-48 h and analyzed by Western blot and the band intensities were measured by densitometer 

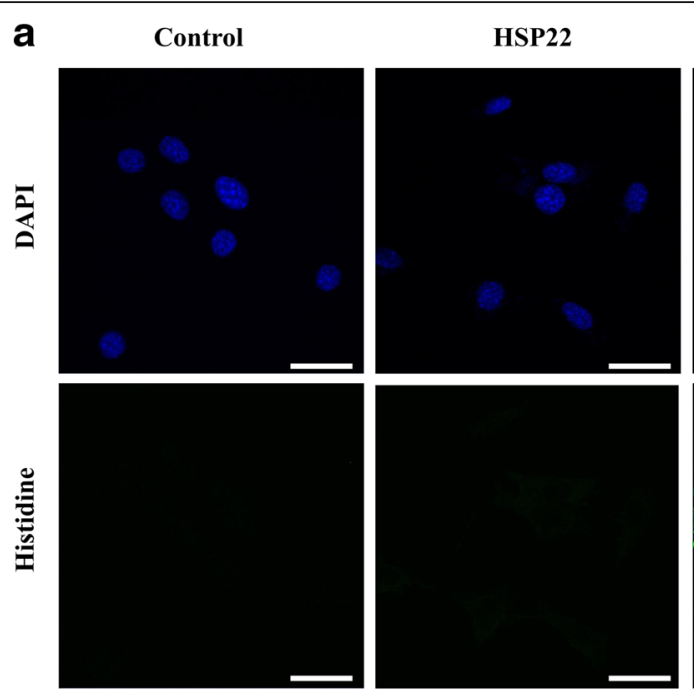

Tat-HSP22
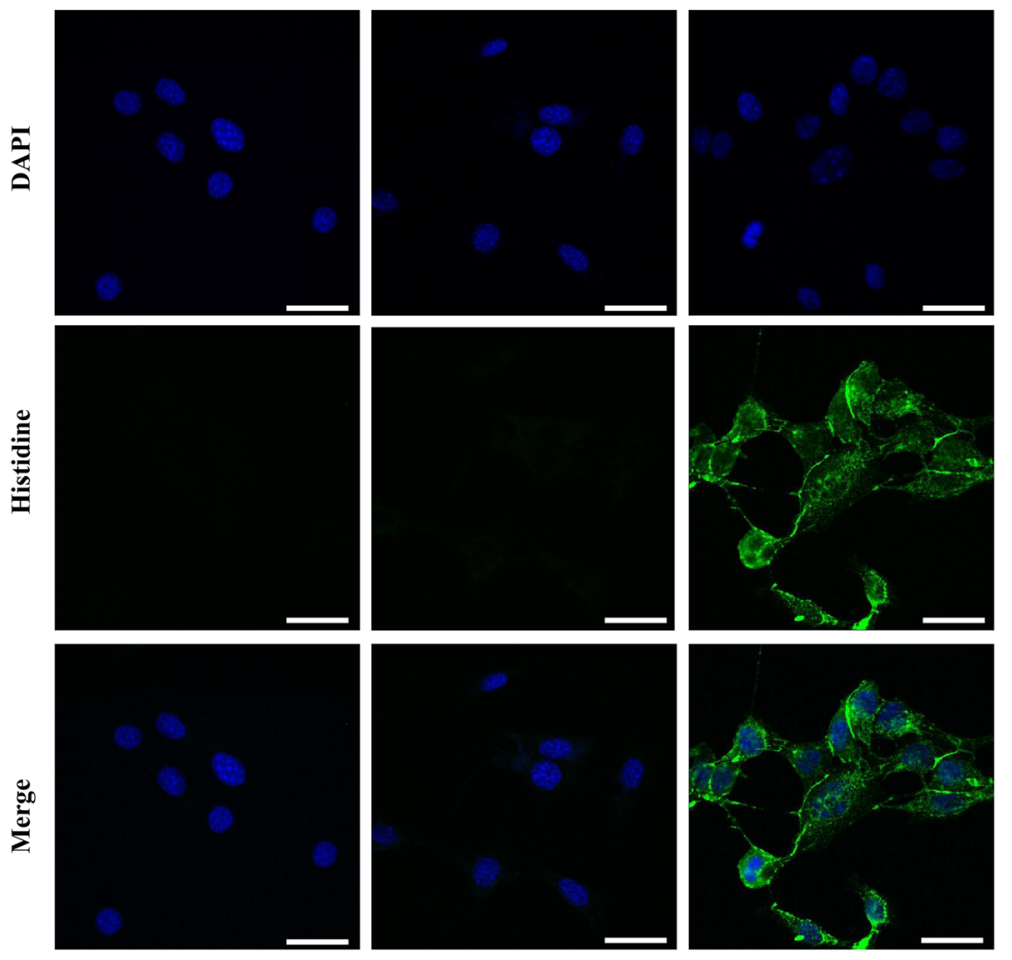

b

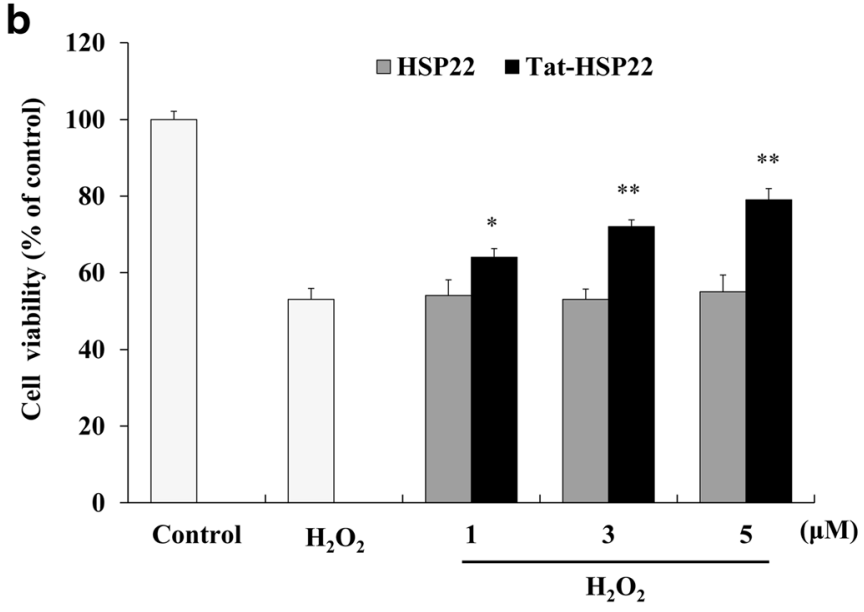

Fig. 3 Transduced Tat-HSP22 protein inhibits $\mathrm{H}_{2} \mathrm{O}_{2}$-induced $\mathrm{HT}$-22 cell death. a Cellular distribution of transduced Tat-HSP22 protein was analyzed using confocal microscopy. HT-22 cells were pretreated with $5 \mu \mathrm{M}$ of Tat-HSP22 or control HSP22 protein for $2 \mathrm{~h}$ and the cells were examined by Histidine and DAPI staining. Scale bar $=20 \mu \mathrm{m}$. b The cells were pretreated with Tat-HSP22 or control HSP22 protein $(5 \mu \mathrm{M})$ for $2 \mathrm{~h}$ and the cells were incubated in the absence or presence of $\mathrm{H}_{2} \mathrm{O}_{2}(1 \mathrm{mM})$ for $12 \mathrm{~h}$. Cell viability was determined using WST-1 assay. ${ }^{* *} P<0.01$ compared with $\mathrm{H}_{2} \mathrm{O}_{2}$-treated cells

Tat-HSP22 protein markedly increased cell viability from 53 to $79 \%$ in the $\mathrm{H}_{2} \mathrm{O}_{2}$ treated cells. In contrast, control HSP22 protein showed no protective effect against $\mathrm{H}_{2} \mathrm{O}_{2}$ induced cell death.

Further, we examined the effects of Tat-HSP22 protein on the production of the intracellular ROS and levels of DNA damage in $\mathrm{H}_{2} \mathrm{O}_{2}$ exposed HT-22 cells by fluorescence staining. The cells were pretreated with Tat-HSP22 protein $(5 \mu \mathrm{M})$ for $2 \mathrm{~h}$ and the cells were exposed to $1 \mathrm{mM} \mathrm{H}_{2} \mathrm{O}_{2}$ for $2 \mathrm{~h}$. Then, the intracellular ROS and DNA damage were determined by DCF-DA and TUNEL staining (Fig. 4). We clearly observed that $\mathrm{H}_{2} \mathrm{O}_{2}$ exposure leads to markedly increased production of intracellular ROS and DNA damage, while cells pretreated with TatHSP22 protein showed drastically reduced intracellular ROS and DNA damage levels compared with $\mathrm{H}_{2} \mathrm{O}_{2}$ 


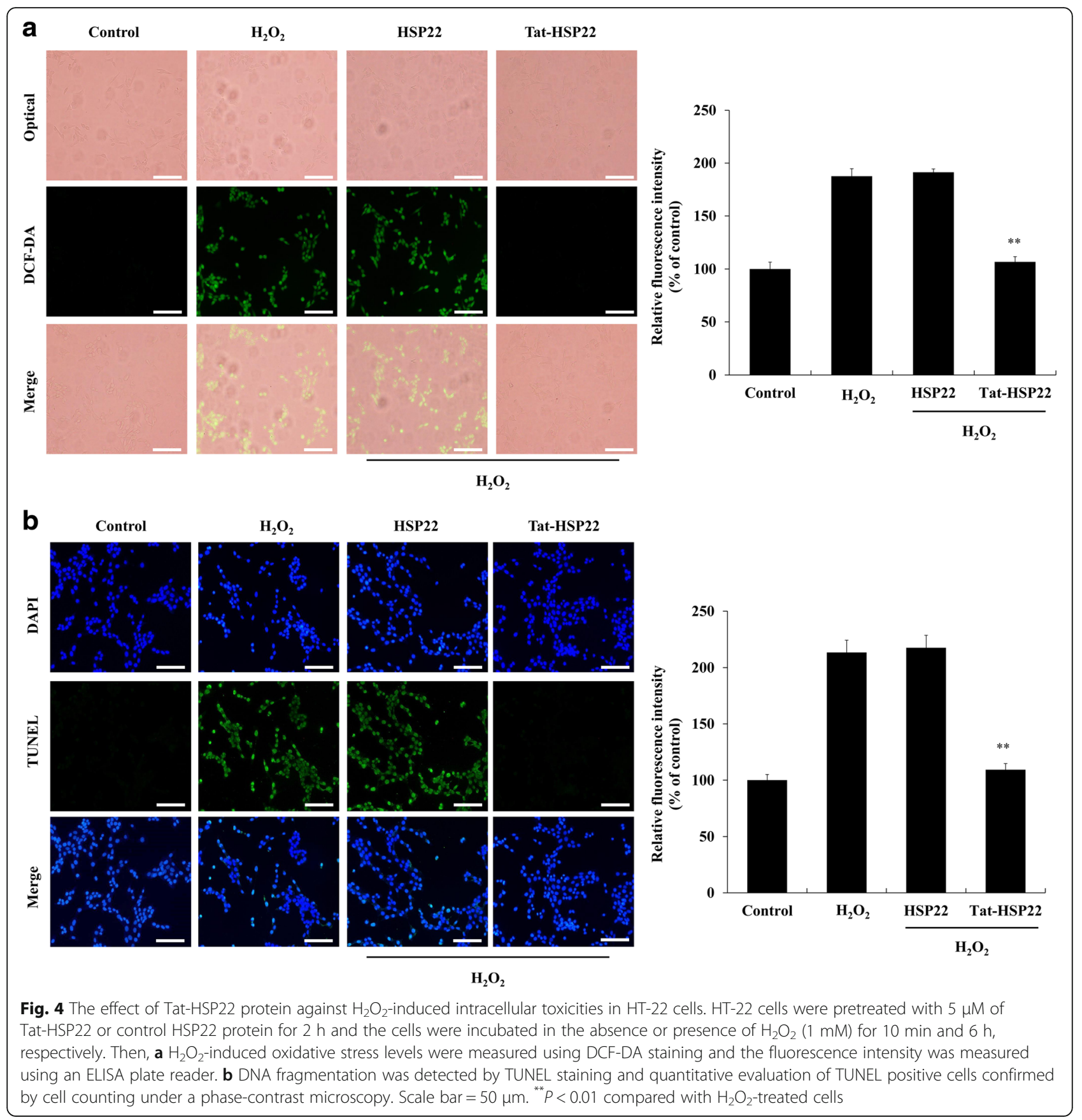

exposed HT-22 cells. In contrast, the results of control HSP22 protein showed no inhibitory effect compared with $\mathrm{H}_{2} \mathrm{O}_{2}$ exposed HT-22 cells, suggesting the effects of TatHSP22 against oxidative stress were caused by inhibiting $\mathrm{H}_{2} \mathrm{O}_{2}$-induced intracellular toxicities.

Tat-HSP22 protein inhibits against $\mathrm{H}_{2} \mathrm{O}_{2}$-induced mitochondrial dysfunction and apoptosis

To elucidate the effects of Tat-HSP22 protein on mitochondrial dysfunction, we assessed changes in the mitochondrial membrane potential using JC-1 staining
(Fig. 5a). The results showed that when HT-22 cells were exposed to $\mathrm{H}_{2} \mathrm{O}_{2}$, mitochondrial membrane potential was significantly increased compared to the normal control or control HSP22 protein treated cells. However, the increased levels of mitochondrial membrane potential in the $\mathrm{H}_{2} \mathrm{O}_{2}$ exposed cells were significantly inhibited by Tat-HSP22 protein.

Next, we determined the inhibitory effects of TatHSP22 protein on the suppression of $\mathrm{H}_{2} \mathrm{O}_{2}$-induced apoptosis. First, we determined the effect of TatHSP22 on transduction into mitochondria of HT-22 


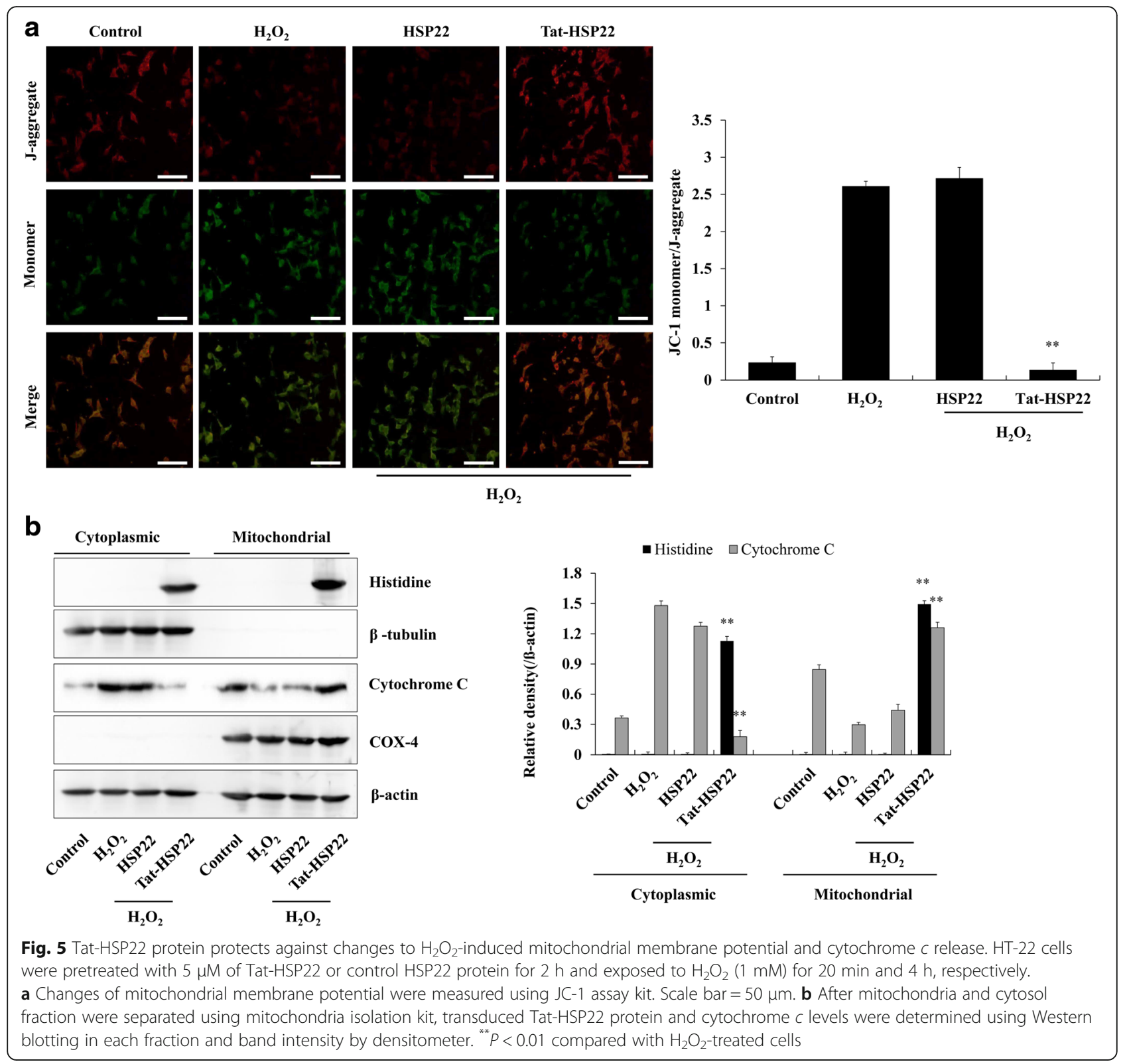

cells and changes of cytochrome $c$ expression levels in separated cytosol and mitochondria fractions (Fig. 5b). We observed that Tat-HSP22 protein increased mitochondria fraction compared to the control cells. In addition, Tat-HSP22 protein markedly inhibited cytochrome $c$ levels in the mitochondria fraction induced by $\mathrm{H}_{2} \mathrm{O}_{2}$. In comparison, control HSP22 protein did not change the cytochrome $c$ levels. The results indicate that transduced Tat-HSP22 protein significantly inhibited cytochrome $c$ release from mitochondria to cytosol induced by oxidative stress, suggesting Tat-HSP22 protein suppresses apoptosis induced by oxidative stress.
Since apoptosis related proteins (Bax, Bcl-2, caspase-3, and cleaved caspase-3) levels were known to change during apoptosis, we determined the expression levels of these proteins (Fig. 6). Tat-HSP22 protein markedly reduced the expression of $\mathrm{Bax}$ and cleaved caspase- 3 levels compared to the cells exposed to $\mathrm{H}_{2} \mathrm{O}_{2}$ alone, while Bcl-2 and caspase- 3 expression levels were significantly increased compared to the $\mathrm{H}_{2} \mathrm{O}_{2}$ exposed cells. However, these protein levels were did not change in control HSP22 protein treated cells under the same experimental condition. These results suggest that the Tat-HSP22 protein protects against oxidative stress-induced apoptosis by regulation of apoptosis related protein expression levels. 


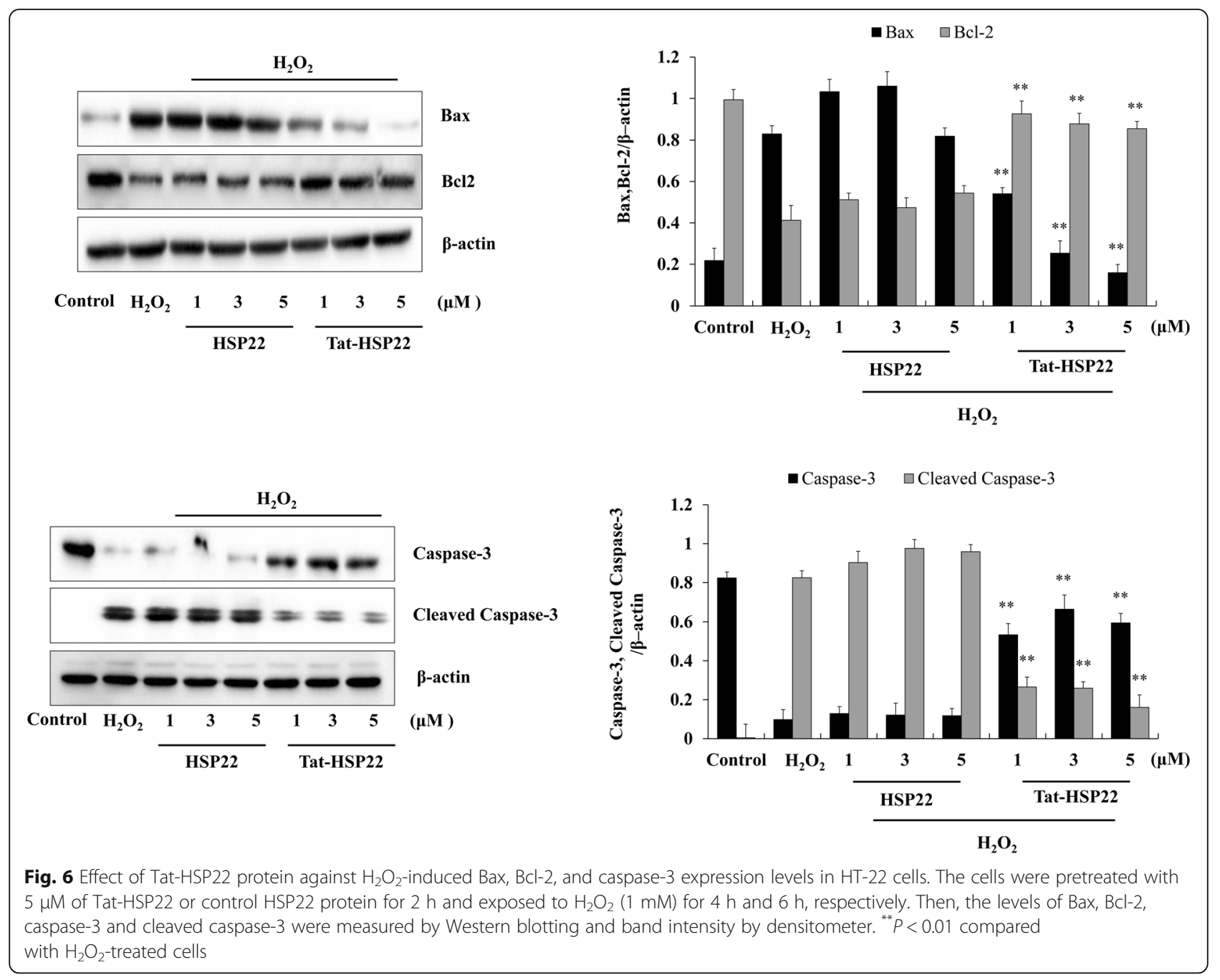

Neuroprotective effects of Tat-HSP22 protein in CA1 region after ischemic damage

We determined the effects of transduced Tat-HSP22 protein on animal brain tissue and its ability to cross the $\mathrm{BBB}$. Because the $\mathrm{BBB}$ prevents the delivery of therapeutic agents into the brain, crossing the $\mathrm{BBB}$ is a key point to protect ischemic injury. To confirm that Tat-HSP22 proteins transduce into the hippocampal CA1 region and protect against ischemic injury, we performed Histidine and NeuN immunostaining. As shown in Fig. 7a, Tat-HSP22 protein transduced into the hippocampal CA1 region of animal brain and markedly protected neurons damage induced by ischemic injury.

We also determined whether cleaved caspase-3 expression was involved in ischemic injury. To confirm the protective effect of Tat-HSP22 protein against ischemic injury derived cleaved caspase- 3 expression, cleaved caspase- 3 and NeuN immunostaining were performed $12 \mathrm{~h}$ after ischemia-reperfusion (Fig. 7b). Immunostaining showed that control HSP22 protein did not protect against ischemic injury. Tat-HSP22 protein significantly prevents the cleaved caspase-3 expression levels induced by ischemic injury, indicating that Tat-HSP22 protein has the ability to transduce into animal brain and protect neurons in the face of ischemic injury.

Further, we examined the protective effects of TatHSP22 protein against ischemic injury (Fig. 8). Cresyl violet $(\mathrm{CV})$ immunohistochemistry showed that TatHSP22 protein markedly increased neuronal cell viability in ischemic injury compared to the vehicle group. In addition, we confirmed neuronal degeneration in the CA1 region using Fluoro-Jade $\mathrm{B}(\mathrm{F}-\mathrm{JB})$ staining since neuronal degeneration causes neuronal cell death. TatHSP22 protein markedly protects against neuronal degeneration induced by ischemic injury. In contrast, control HSP22 protein showed the similar results as the vehicle group. Our results demonstrate that Tat-HSP22 protein efficiently promotes neuronal cell survival induced in ischemic injury. 


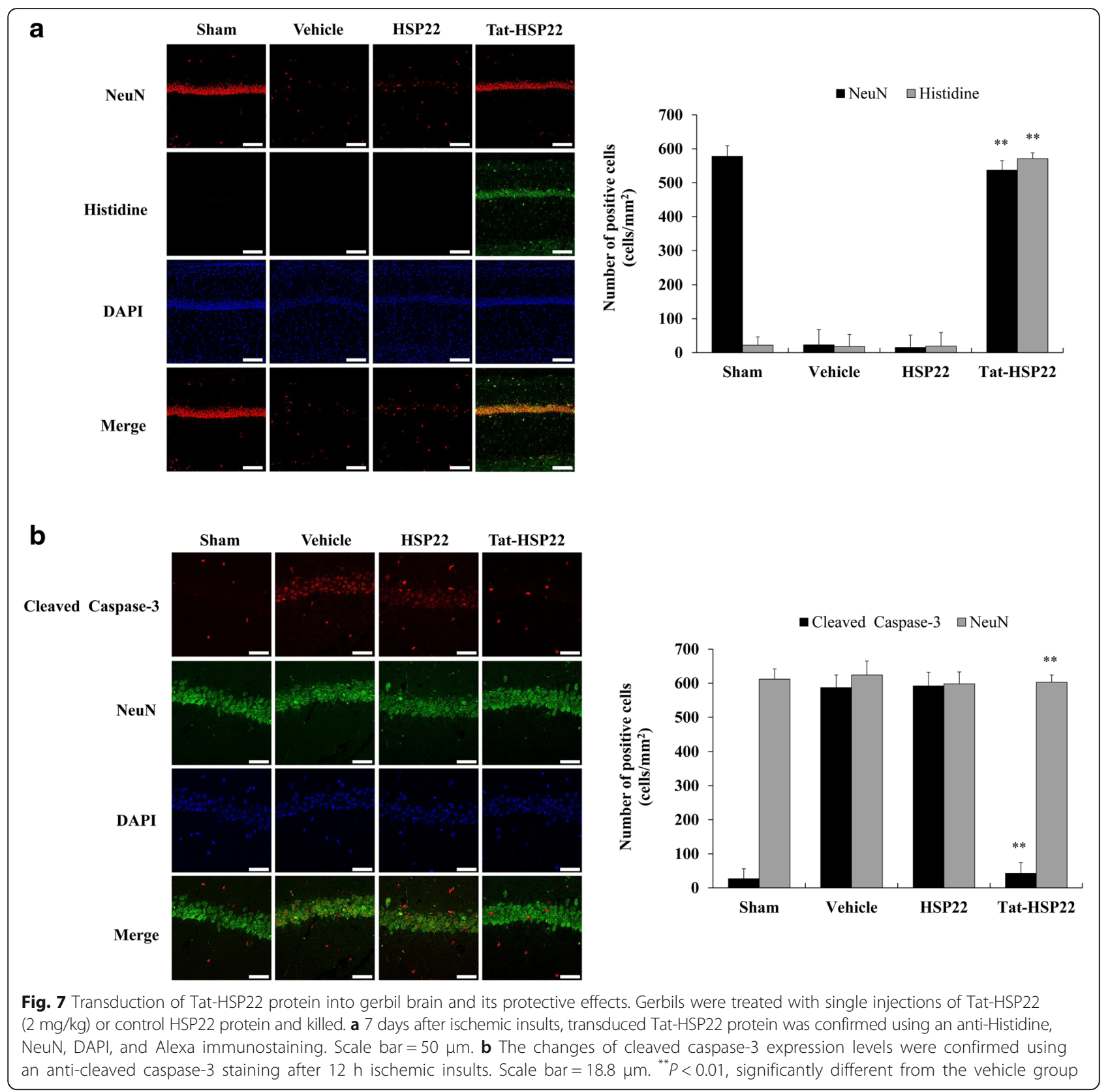

Since the activation of astrocytes and microglia are known to be strongly involved in ischemic injury, we further performed GFAP and Iba-1 staining to detect whether Tat-HSP22 protein prevents astrocytes and microglia activation induced by ischemic injury. GFAP and Iba- 1 staining showed that control HSP22 protein demonstrated a similar pattern as the vehicle group, while Tat-HSP22 protein drastically protected against astrocytes and microglia activation induced by ischemic injury. As shown in Fig. 8, our results indicate that TatHSP22 protein significantly prevented the neuronal cell death in the CA1 region induced by ischemic injury.

\section{Discussion}

Heat shock protein 22 (HSP22) known as H11 kinase, E21G1, and HSPB8 is a member of the small HSP family of proteins containing a $\alpha$-crystalline domain and has been demonstrated to have protective effect against various conditions including oxidative stress, aging, cancer, and apoptosis [8-13]. Although HSP22 protein is well known to function in the pathophysiological processes of various cancer cells, the exact function and mechanism of HSP22 protein in hippocampal neuronal cell damage from oxidative stress and in an ischemic brain injury animal model remains to be clarified. Therefore, we investigated the effects of HSP22 protein against 


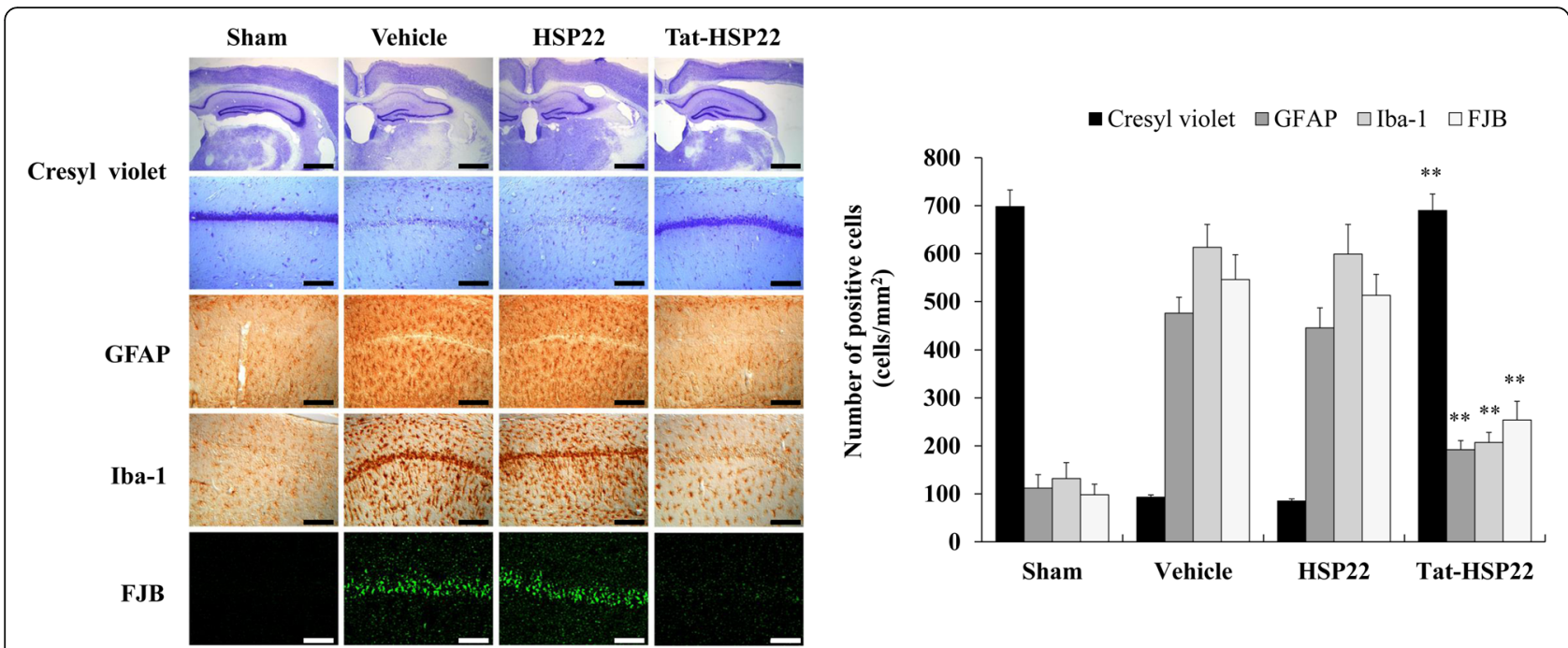

Fig. 8 Neuroprotective effects of Tat-HSP22 protein against ischemic damage. Gerbils were treated with single injections Tat-HSP22 (2 mg/kg) or control HSP22 protein and killed after 7 days. Neuronal cell viability after ischemic insults were determined using Cresyl violet, GFAP, Iba-1, and F-JB immunostaining. Relative numeric analysis of CV, GFAP, Iba-1, and F-JB positive neurons in the CA1 region. Scale bar $=400 \mathrm{and} 50 \mu \mathrm{m}$.

${ }^{* *} P<0.01$, significantly different from the vehicle group

oxidative stress-induced neuronal cell damage to clarify the function and mechanism used Tat-HSP22 protein, which is known for the ability to be efficiently delivered into cells or tissues. Since HIV-1 Tat protein transduction domain (PTD) fusion protein has the ability to efficiently transduce into cells by crossing the plasma membrane or brain tissue therefore crossing the blood-brain barrier (BBB), numerous studies have demonstrated the potential of its therapeutic protein application in cells or tissues against various diseases [11, 17-26].

In this study, we constructed the recombinant TatHSP22 protein expression vector and purified TatHSP22 protein with Ni-NTA affinity chromatography. Purified Tat-HSP22 protein was evaluated by SDS-PAGE and Western blot analysis. We subsequently confirmed the transduction ability of Tat-HSP22 protein into HT22 cells. Our data showed that Tat-HSP22 protein transduced into HT-22 cells dose- and time-dependently. In addition, we confirmed the distribution of transduced Tat-HSP22 protein in HT-22 cells by immunofluorescence staining. Transduced Tat-HSP22 protein distributed in the cytosol and nuclei of HT-22 cells. These results indicate that we successfully constructed TatHSP22 protein expression vector and purified TatHSP22 protein efficiently transduced into HT-22 cells. Consistent with other studies, which have demonstrated that various purified PTD fusion proteins efficiently transduce into cells $[19-25,27,28]$.

Hydrogen peroxide $\left(\mathrm{H}_{2} \mathrm{O}_{2}\right)$, a mild oxidant, is a known by-product of a normal biological processes in cells. However, high levels of $\mathrm{H}_{2} \mathrm{O}_{2}$ are very toxic and critical for cell survival and signaling pathways because reactive oxygen species (ROS) including superoxide anion and hydroxyl radical are produced in the presence of high levels of $\mathrm{H}_{2} \mathrm{O}_{2}$ [29-31]. Also, generated ROS is well known to contribute to cellular damage by destroying macromolecules including proteins, lipids, and nucleotides [32]. Thus, we examined the effect of Tat-HSP22 protein against $\mathrm{H}_{2} \mathrm{O}_{2}$-induced cellular toxicities. We demonstrated that transduced Tat-HSP22 protein significantly increased cell survival compared to the cells treated only with $\mathrm{H}_{2} \mathrm{O}_{2}$-treated. Also, Tat-HSP22 protein markedly inhibited $\mathrm{H}_{2} \mathrm{O}_{2}$-induced intracellular oxidative stress and DNA fragmentation levels compared to the $\mathrm{H}_{2} \mathrm{O}_{2}$-treated cells. Other studies have shown that overexpression of HSP22 promotes cardiac cell survival and HSP22 has protective effects in the stress condition of cardiac cells via regulating the PI3K/Akt pathways [33]. Also, overexpression of HSP22 increased resistance to oxidative stress and longevity in flies whereas the absence of HSP22 expression decreased the lifespan and resistance to stress, suggesting that HSP22 overexpression play beneficial roles during aging $[34,35]$. In agreement with these results, we have shown that transduced Tat-HSP22 protein prevents HT-22 cell death caused by $\mathrm{H}_{2} \mathrm{O}_{2}$-induced oxidative stress.

Several studies have demonstrated that mitochondria is the main generator of ROS and excessive ROS eventually leads to mitochondria dysfunction and cell death by induction of apoptosis in various conditions including aging and ischemic injury [36-38]. Further, apoptosis is known to play a critical role in the survival of cells in various conditions including ischemia. The balance of pro-apoptotic (Bax) and anti-apoptotic (Bcl-2) proteins 
is important to cell survival. Activation of Bax induced cell death by cytochrome $c$ release from the mitochondria and activation of caspase-3 $[39,40]$. Thus, we determined the effect of transduced Tat-HSP22 protein on $\mathrm{H}_{2} \mathrm{O}_{2}$-induced mitochondria apoptotic signal pathway. Tat-HSP22 protein significantly prevented mitochondrial dysfunction and inhibited the release of cytochrome $c$ from mitochondria to cytosol as well as inhibited cell death via regulation of the expression of the apoptotic proteins Bax, Bcl-2, and active caspase-3. Corroborating our results, other studies have demonstrated that overexpression of HSP22 protein increase resistance to oxidative stress and prevents mitochondrial dysfunction by reducing ROS production during the aging process of flies [14]. Also, overexpression of HSP22 protein inhibits the mitochondria dependent apoptosis through regulation of pro-apoptotic and anti-apoptotic proteins expression in myocardial infarction [41].

Since it is difficult to cross the BBB it is difficult to deliver therapeutic drugs or agents into brain, the therapeutic effects of drugs or agents is limited in neuronal diseases including ischemia. However, PTD fusion proteins are known to be able to delivery therapeutic proteins into the brain which is considered a powerful tool in the development of therapeutic drugs or agents in neuronal diseases $[17-19,42]$. In a previous study, we demonstrated that Tat fused protein inhibited neuronal cell death in ischemic injury via crossing the BBB [22]. In this study, we determined the effect of Tat-HSP22 protein against ischemia in an animal model. Our results showed that Tat-HSP22 protein efficiently transduced into the hippocampal CA1 region where it markedly inhibited neuronal cell death. Tat-HSP22 protein also decreased active caspase- 3 expression levels in the hippocampal CA1 region. Several studies have shown that HSP22 protein expression is increased in a swine ischemia model and in ischemia patients, suggesting that HSP22 protein plays protective roles in ischemic injury [43, 44]. In addition, HSP22 protein enhances cardiac cell survival by prevention of myocardial infarction in ischemic preconditioning [41]. Other studies have also shown that increased HSP22 mRNA is associated with the improvement in renal function after ischemia [45].

Several studies have demonstrated that the activation of microglia and astrocytes as well as the expression of abundant glial fibrillary acidic protein are highly associated with neuronal diseases including ischemic injury [46-49]. Using GFAP, Iba-1, and F-JB immunohistochemistry, we demonstrated that Tat-HSP22 protein markedly reduced activation of microglia and astrocytes as well as the expression of glial fibrillary acidic protein in the hippocampal CA1 region. These results indicate that Tat-HSP22 protein plays an important role in preventing neuronal damage via regulation of gliosis and neuronal degeneration resulting from ischemia. However, further studies are required to understand the exact mechanisms in ischemic injury.

In conclusion, we showed that Tat-HSP22 protein transduced into hippocampal HT-22 cells in vitro and the CA1 region in vivo and significantly inhibited neuronal cell death caused by oxidative stress, suggesting that Tat-HSP22 protein provides a potential therapeutic strategy to prevent oxidative stress-induced diseases including ischemic injury.

\section{Methods}

\section{Cell culture and cell viability assay}

Hippocampal neuronal cells (HT-22) were cultured as described previously [27]. To assess cell viability, HT22 cells were preincubated with Tat-HSP22 or control HSP22 $(1-5 \mu \mathrm{M})$ for $2 \mathrm{~h}$ before treatment with hydrogen peroxide $(1 \mathrm{mM})$ for $12 \mathrm{~h}$. Cell viability was determined by a WST-1 kit (Daeillab Service, Seoul, Korea) [27].

\section{Construction, purification, and transduction of recombinant Tat-HSP22 into HT-22}

The HSP22 full length cDNA amplification was performed using human HSP22 specific primers as follows; the primer of forward as 5' -CTCGAGATGGCTGACGGTCAG$3^{\prime}$ and the primer of reverse as $5^{\prime}$-GGATCCTCAGGTAC AGGTGACTTCCT-3'. Subsequently, we constructed cell permeable Tat-HSP22 and control HSP22 expression vector as previously described [22].

After transformation of constructed Tat-HSP22 and control HSP22 protein expression vector into Escherichia coli BL21 (DE3), these plasmids were cultured in $\mathrm{LB}$ medium at $37^{\circ} \mathrm{C}$ for $4 \mathrm{~h}$ including ampicillin $(50 \mu \mathrm{g} /$ $\mathrm{ml})$ and IPTG $(0.5 \mathrm{mM})$ to purify Tat-HSP22 and control HSP22 protein. Then, overexpressed Tat-HSP22 and control HSP22 proteins were harvested by centrifugation and the proteins were purified using affinity chromatograph as described in a previous study [22]. Purified TatHSP22 protein concentration was determined using a Bradford assay [50].

For transduction of Tat-HSP22 into HT-22, the proteins were added to the HT-22 culture medium at different concentrations $(0.5-5 \mu \mathrm{M})$ for $2 \mathrm{~h}$ or treated over various times $(10-120 \mathrm{~min})$ at the same level $(5 \mu \mathrm{M})$. Then, the HT-22 was washed with trypsinEDTA and PBS. The levels of transduced Tat-HSP22 was identified by Western blotting and confocal microscope analysis (FV-300; Olympus, Tokyo, Japan) [23]. Western blotting was performed as previously described [23, 51]. The protein bands were analyzed ECL (Amersham, Franklin Lakes, NJ, USA) using the indicated specific antibody. 


\section{Fluorescence microscopy analysis}

To detect the intracellular distribution of transduced Tat-HSP22 into HT-22, fluorescence microscopy was performed as described previously [24]. After exposure of HT-22 to Tat-HSP22 $(5 \mu \mathrm{M})$ for $2 \mathrm{~h}$, the cells were washed twice with PBS. Subsequently, the cells were staining with Histidine primary $\mathrm{Ab}$ and Alexa Fluor 488-conjugated secondary Ab. After washing, the cells were staining with DAPI (Roche, Mannheim, Germany) and observed under a FV-300 confocal microscope (Olympus, Tokyo, Japan).

\section{Measurement of intracellular toxicities}

To examine the function of Tat-HSP22 against oxidative stress-induced HT-22 cell toxicities, HT-22 were treated with Tat-HSP22 $(5 \mu \mathrm{M})$ after exposure or non-exposure to hydrogen peroxide for $2 \mathrm{~h}$. Then, the hydrogen peroxide-induced cellular toxicities including cellular ROS (DCF-DA staining), DNA fragmentation (TUNEL staining), and mitochondria dysfunction levels (JC-1 staining) were measured by fluorescence microscopy analysis [22-24, 52].

\section{Experimental animals}

Male gerbils obtained from the Experimental Animal Center, at Hallym University were housed at $23{ }^{\circ} \mathrm{C}$, with humidity of $60 \%$, and exposed to $12 \mathrm{~h}$ periods of light and dark with free access to food and water. All experimental procedures involving animals and their care conformed to the Guide for the Care and Use of Laboratory Animals of the National Veterinary Research \& Quarantine Service of Korea and were approved by the Institutional Animal Care and Use Committee of Soonchunhyang University [SCH 15-0005].

\section{Effects of Tat-HSP22 on ischemic animal model}

To investigate the effects of HSP22 against ischemic insults, the animals were divided into 4 groups ( 7 gerbils in each groups). Group 1, sham operated control group; group 2, ischemia operated vehicle group; group 3, control HSP22 protein $(2 \mathrm{mg} / \mathrm{kg})+$ ischemia operated group; group 4, Tat-HSP22 protein $(2 \mathrm{mg} / \mathrm{kg})+$ ischemia operated group. Control HSP22 and Tat-HSP22 proteins were intraperitoneally injected $30 \mathrm{~min}$ after ischemia-reperfusion.

In addition, we examined changes in cleaved caspase-3 expression levels caused by Tat-HSP22 protein in an ischemic animal model. $30 \mathrm{~min}$ after ischemia-reperfusion, control HSP22 and Tat-HSP22 proteins were intraperitoneally injected, the animals were sacrificed after $12 \mathrm{~h}$ to confirm the changes of cleaved caspase- 3 expression levels by immunostaining.

Induction of ischemic injury was performed as previously described [22, 27]. Briefly, ischemia was induced by the occlusion of arteries with non-traumatic aneurysm clips. 7 days after induction of ischemic injury, the effects of HSP22 proteins were examined by immunohistochemistry [22, 27, 28].

\section{Immunostaining and immunohistochemistry analysis}

To determine the effects of transduced Tat-HSP22 protein against neuronal cell death and changes of cleaved-capase- 3 expression levels in ischemic animal model, NeuN, histidine, and cleaved caspase-3 immunostaining were performed. Briefly, the sections were stained with NeuN (diluted 1:1,000; Chemicon International, Temecula, CA, USA), histidine (diluted 1:1,000; Santa Cruz, CA, USA), cleaved caspase-3 (diluted 1:1,000; Cell Signaling Technology, Beverly, MA, USA). The sections were also incubated in a mixture of FITCand Cy3-conjugated secondary antisera (1:200; Amersham, USA) for $1 \mathrm{~h}$ and mounted with DAPI (Vector, Laboratories, CA, USA).

To determine the effect of transduced Tat-HSP22 protein against neuronal cell survival and delayed neuronal damage in ischemic animal model, we performed CV, GFAP, Iba-1, and F-JB immunohistochemistry as previously described $[22,27,28]$.

\section{Cell counting and statistical analysis}

For quantification of immunostaining, we performed a cell count in the hippocampal area as described in a previous study [22, 27, 28]. All data are presented as the mean \pm SEM. The different between the groups were analyzed using one-way ANOVA with Bonferroni's test. A value of $P<0.05$ was considered statistically significant different.

\section{Abbreviations \\ Ab: Antibody; BBB: Blood-brain barrier; CV: Cresyl violet; DAPI: 4',6-diamidino- 2-phenylindole; DCF-DA: 2'7'-dichlorofluorescein diacetate; ECL: Enhanced chemiluminescence; F-JB: Fluoro-Jade B; GFAP: Glial fibrillary acidic protein; $\mathrm{H}_{2} \mathrm{O}_{2}$ : Hydrogen peroxide; HSP22: Heat shock protein 22; lba-1: lonized calcium-binding adapter molecule 1; IPTG: Isopropyl-ß-D-thiogalactopyranoside; NeuN: Neuronal neclei; PBS: Phosphate-buffered saline; PTD: Protein transduction domain; ROS: Reactive oxygen species}

\section{Acknowledgements}

Not applicable.

\section{Funding}

This work was supported by a Priority Research Centers Program grant (2009-0093812) and Mid-Career Researcher Program grant (2016R1A2B4008356) through the National Research Foundation of Korea funded by the Ministry of Education, and Ministry of Science, ICT \& Future Planning, and also this study was supported by Basic Science Research Program through the National Research Foundation of Korea funded by the Ministry of Education (2015R1D1A3A01015668) in the Republic Korea. 


\section{Authors' contributions}

HSJ, DWK and MJS carried out the design and experiments. SBC, JHP, CHL, EJY and YJC contributed reagent/analytic tools. DSK and YHY performed animal experiments. EJS, OS, SWC, DSK, YHY, KWL and JP analysis and interpretation of data. WSE and SYC carried out the design of the study and wrote the paper. All authors read and approved the final manuscript.

\section{Competing interests}

The authors declare that they have no competing interests.

\section{Consent for publication}

Not applicable.

\section{Ethics approval and consent to participate}

All experimental procedures involving animals and their care conformed to the Guide for the Care and Use of Laboratory Animals of the National Veterinary Research \& Quarantine Service of Korea and were approved by the Institutional Animal Care and Use Committee of Soonchunhyang University [SCH 15-0005]

\section{Author details}

'Department of Biomedical Science and Research Institute of Bioscience and Biotechnology, Hallym University, Chuncheon 24252, Korea. ${ }^{2}$ Department of Biochemistry and Molecular Biology, Research Institute of Oral Sciences, College of Dentistry, Gangneung-Wonju National University, Gangneung 25457, Korea. ${ }^{3}$ Department of Biochemistry and Molecular Biology, University of Ulsan College of Medicine, Seoul 05505, Korea. ${ }^{4}$ Department of Anatomy, College of Medicine, Soonchunhyang University, Cheonan-Si 31538, Korea.

\section{Received: 20 September 2016 Accepted: 12 December 2016}

\section{Published online: 04 January 2017}

\section{References}

1. Ellis RJ. Protein misassembly: macromolecular crowding and molecular chaperones. Adv Exp Med Biol. 2007:594:1-13.

2. Kelly S, Yenari MA. Neuroprotection: heat shock proteins. Curr Med Res Opin. 2002;18:55-60

3. Hendrick JP, Hartl FU. Molecular chaperone functions of heat-shock proteins. Annu Rev Biochem. 1993;62:349-84.

4. Vos MJ, Hageman J, Carra S, Kampinga HH. Structural and functional diversities between members of the human HSPB, HSPH, HSPA, and DNAJ chaperone families. Biochem. 2008;47:7001-11.

5. Fu X. Chaperone function and mechanism of small heat-shock proteins. Acta Biochim Biophys Sin. 2014;46:347-56.

6. Treweek TM, Meehan S, Ecroyd H, Carver JA. Small heat-shock proteins: important players in regulating cellular proteostasis. Cell Mol Life Sci. 2015;72:429-51

7. Taylor RP, Benjamin IJ. Small heat shock proteins: a new classification scheme in mammals. J Mol Cell Cardiol. 2005;38:433-44.

8. Chowdary TK, Raman B, Ramakrishna T, Rao CM. Mammalian Hsp22 is a heat-inducible small heat-shock protein with chaperone-like activity. Biochem J. 2004:381:379-87.

9. Colinet H, Lee SF, Hoffmann A. Knocking down expression of Hsp22 and Hsp23 by RNA interference affects recovery from chill coma in Drosophila melanogaster. J Exp Biol. 2010;213:4146-50.

10. Magdalena LM, Coipan EC, Vladimirescu AF, Savu L, Costache M, Gavrila L. Down regulation of hsp22 gene expression in Drosophila melanogaster from sites located near chemical plants. Genet Mol Res. 2012;11:739-45.

11. Suzuki M, Matsushima-Nishiwaki R, Kuroyanagi G, Suzuki N, Takamatsu R, Furui T, et al. Regulation by heat shock protein 22 (HSPB8) of transforming growth factor-a-induced ovary cancer cell migration. Arch Biochem Biophys. 2015;571:40-9.

12. Rashed E, Lizano P, Dai H, Thomas A, Suzuki CK, Depre C, et al. Heat shock protein 22 (Hsp22) regulates oxidative phosphorylation upon its mitochondrial translocation with the inducible nitric oxide synthase in mammalian heart. PLoS One. 2015;10:e01195357.

13. Laure L, Long R, Lizano P, Zini R, Berdeaux A, Depre C, et al. Cardiac H11 kinase/Hsp22 stimulates oxidative phosphorylation and modulates mitochondrial reactive oxygen species production: Involvement of a nitric oxide-dependent mechanism. Free Radic Biol Med. 2012;52:2168-76.
14. Morrow G, Pecheur ML, Tanguay RM. Drosophila melanogaster mitochondrial Hsp22: a role in resistance to oxidative stress, aging and the mitochondrial unfolding protein response. Biogerontol. 2016;17:61-70.

15. Murphy MP. How mitochondria produce reactive oxygen species. Biochem J. 2009:417:1-13.

16. Schieber M, Chandel NS. ROS function in redox signaling and oxidative stress. Curr Biol. 2014;24:R453-62.

17. Wadia JS, Dowdy SF. Protein transduction technology. Curr Opin Biotechnol. 2002;13:52-6.

18. Schwarze S, Ho A, Vocero-Akbani A, Dowdy SF. In vivo protein transduction: Delivery of a biologically active protein into the mouse. Science. 1999;285:1569-72.

19. Dietz GP. Cell-penetrating peptide technology to deliver chaperones and associated factors in diseases and basic research. Curr Pharm Biotechnol. 2010;11:167-74

20. van den Berg A, Dowdy SF. Protein transduction domain delivery of therapeutic macromolecules. Curr Opin Biotechnol. 2011:22:888-93.

21. Eom SA, Kim DW, Shin MJ, Ahn EH, Chung SY, Sohn EJ, et al. Protective effects of PEP-1-Catalase on stress-induced cellular toxicity and MPTPinduced Parkinson's disease. BMB Rep. 2015;48:395-400.

22. Shin MJ, Kim DW, Lee YP, Ahn EH, Jo HS, Kim DS, et al. Tat-glyoxalase protein inhibits against ischemic neuronal cell damage and ameliorates ischemic injury. Free Radic Biol Med. 2014;67:195-210.

23. Kim MJ, Kim DW, Park JH, Kim SJ, Lee CH, Yong Jl, et al. PEP-1-SIRT2 inhibits inflammatory response and oxidative stress-induced cell death via expression of antioxidant enzymes in murine macrophages. Free Radic Biol Med. 2013;63:432-45.

24. Kim MJ, Park M, Kim DW, Shin MJ, Son O, Jo HS, et al. Transduced PEP-1-PON1 protein regulate microglial activation and dopaminergic neuronal death in a Parkinson's model. Biomaterials. 2015:64:45-56.

25. Kim DW, Lee SH, Ku SK, Lee JE, Cha HJ, Youn JK, et al. The effects of PEP-1-FK506BP on dry eye disease in a rat model. BMB Rep. 2015:48:153-8.

26. Zhang Z, Huang L, Wu Q, Yang E, Zhang G, Sun H, et al. A recombinant trans-membrane protein hMnSOD-R9 inhibits the proliferation of cervical cancer cells in vitro. Mol Cell Biochem. 2014;385:79-86.

27. Kim YN, Jung HY, Eum WS, Kim DW, Shin MJ, Ahn EH, et al. Neuroprotective effects of PEP-1-carbonyl reductase 1 against oxidative stress-induced ischemic neuronal cell damage. Free Radic Biol Med. 2014;69:181-96

28. Jeong HJ, Yoo DY, Kim DW, Yeo HJ, Cho SB, Hyeon J, et al. Neuroprotective effect of PEP-1-peroxiredoxin2 on CA1 regions in the hippocampus against ischemic insults. Biochim Biophys Acta. 1840;2014:2321-30.

29. Halliwell B, Gutteridge JMC. Free radicals in biology and medicine. Oxford: Oxford University Press; 1999

30. Rhee SG, Chang TS, Jeong W, Kang D. Methods for detection and measurement of hydrogen peroxide inside and outside of cells. Mol Cells. 2010;29:539-49.

31. Pi J, Zhang Q, Fu J, Woods CG, Hou Y, Corkey BE, et al. ROS signaling, oxidative stress and Nrf2 in pancreatic beta-cell function. Toxicol Appl Pharm. 2010;244:77-83.

32. Pierre $J \mathrm{~L}$, Fontecave M. Iron and activated oxygen species in biology: the basic chemistry. Biometals. 1999;12:195-9.

33. Sui X, Li D, Oiu H, Gaussin V, Depre C. Activation of the bone morphogenetic protein receptor by $\mathrm{H} 11$ Kinase/Hsp22 promotes cardiac cell growth and survival. Cir Res. 2009;104:887-95.

34. Morrow G, Samson M, Michaud S, Tanguay RM. Overexpression of the small mitochondrial Hsp22 extends Drosophila life span and increases resistance to oxidative stress. FASEB J. 2004;18:598-9.

35. Morrow G, Battistini S, Zhang P, Tanguay RM. Decreased lifespan in the absence of expression of the mitochondrial small heat shock protein Hsp22 in Drosophila. J BiolChem. 2004;279:43382-5.

36. Genova ML, Lenaz $\mathrm{G}$. The interplay between respiratory supercomplexes and Ros in aging. Antioxid Redox Signal. 2015;23:208-38

37. Holzerova E, Prokisch H. Mitochondria: much ado about nothing? How dangerous is reactive oxygen species production? Int J Biochem Cell Biol. 2015;63:16-20.

38. Chouchani ET, Pell VR, Gaude E, Aksentijevic D, Sundier SY, Robb EL, et al. Ischaemic accumulation of succinate controls reperfusion injury through mitochondrial ROS. Nature. 2014;515:431-5.

39. Bandyopadhaya A, Constantinou C, Psychogios N, Ueki R, Yasuhara S, Martyn JA, et al. Bacterial-excreted small volatile molecule 2- 
aminoacetophenone induces oxidative stress and apoptosis in murine skeletal muscle. Int J Mol Med. 2016;37:867-78.

40. Tien YC, Lin JY, Lai CH, Kuo CH, Lin WY, Tsai CH, et al. Carthamus tinctotius L. prevent LPS-induced TNFa signaling activation and cell apoptosis through JNK1/ 2-NFkB pathway inhibition in H9c2 cardiomyoblast cells. J Ethnopharmacol. 2010;130:505-13.

41. Depre C, Wang L, Sui X, Qiu H, Hong C, Hedhli N, et al. H11 kinase prevents myocardial infarction by preemptive conditioning of the heart. Circ Res. 2006;98:280-8.

42. Ramsey JD, Flynn NH. Cell-penetrating peptides transport therapeutics into cells. Pharmacol Therapeut. 2015;154:78-86.

43. Depre C, Tomlinson JE, Kudej RK, Gaussin V, Thompson E, Kim SJ, et al. Gene program for cardiac cell survival induced by transient ischemia in conscious pig. Proc Natl Acad Sci U S A. 2001;98:9336-41.

44. Depre C, Kim SJ, John AS, Huang Y, Rimoldi OE, Pepper JR, et al. Program of cell survival underlying human and experimental hibernating myocardium. Circ Res. 2004;95:433-40.

45. Kelly KJ, Baird NR, Greene AL. Induction of stress response proteins and experimental renal ischemia/reperfusion. Kidney Int. 2001;59:1798-802.

46. Pekny M, Nilsson M. Astrocyte activation and reactive gliosis. Glia. 2005;50:427-34.

47. Ito D, Tanaka K, Suzuki S, Dembo T, Fukuuchi Y. Enhanced expression of Iba1, ionized calcium-binding adapter molecule 1, after transient focal cerebral ischemia in rat brain. Stroke. 2001;32:1208-15.

48. Park JH, Shin BN, Chen BH, Kim IH, Ahn JH, Cho JH, et al. Neuroprotection and reduced gliosis by atomoxetine pretreatment in a gerbil model of transient cerebral ischemia. J Neurol Sci. 2015;359:373-80.

49. Ko AR, Kang TC. Mannitol induces selective astroglial death in the CA region of the rat hippocampus following status epilepticus. BMB Rep. 2015:48:507-12.

50. Bradford M. A rapid and sensitive method for the quantitation of microgram quantities utilizing the principle of protein-dye binding. Anal Biochem. 1976;72:248-54.

51. Ju SM, Youn GS, Cho YS, Choi SY, Park J. Celastrol ameliorates cytokine toxicity and pro-inflammatory immune responses by suppressing NF-kB activation in RINm5F beta cells. BMB Rep. 2015;48:172-7.

52. Choi SH, Park BK, Lee KW, Chang J, Lee Y, Kwon HJ. Effect of respiratory syncytial virus on the growth of hepatocellular carcinoma cell-lines. BMB Rep. 2015;48:565-70

\section{Submit your next manuscript to BioMed Central and we will help you at every step:}

- We accept pre-submission inquiries

- Our selector tool helps you to find the most relevant journal

- We provide round the clock customer support

- Convenient online submission

- Thorough peer review

- Inclusion in PubMed and all major indexing services

- Maximum visibility for your research

Submit your manuscript at www.biomedcentral.com/submit

) Biomed Central 